\title{
A STUDY OF VARIOUS FACTORS AFFECTING RISK MANAGEMENT TECHNIQUES IN CONSTRUCTION PROJECT: A CASE STUDY OF INDIA
}

\author{
Shuaibu Saminu ${ }^{1}$, Raj Prasad ${ }^{2}$, V. Thamilarasu ${ }^{3}$ \\ ${ }^{I} P G$ Student, Department of Civil Engineering, SRM University, Chennai, India \\ ${ }^{2}$ Assistant Professor, Department of Civil Engineering, SRM University, Chennai, India \\ ${ }^{3}$ Professor, Department of Civil Engineering, SRM University, Chennai, India
}

\begin{abstract}
Risk management is an important step which should not be neglect or ignore in every project. Because of various risk involved in construction, it is difficult to maintain time, cost and quality as planned. Project undertaken in the construction sector are widely complex and have often significant budgets, and thus reducing the risk associated should be a priority for each project manager. The main purpose of this paper is to identify the key risk factors that affect construction project. Questionnaires has been prepared incorporating of 50 difference questions after which questionnaire survey was conducted where the questions has been focused based on (component of questionnaire) the respondents were selected based on their susceptibility to the risk. The data was analyzed using the Statistical package for social sciences (SPSS) version 21. The result shows that the inadequate planning in construction project, poor adoption of site safety, supply and use of defective materials and poor resources management in construction project are all among the forefront key risk factors which affect construction project, meanwhile, effective recommendations have been developed to increases the efficiency, speedy and minimises risk and abortive work in construction project.
\end{abstract}

Keywords: Construction Industries, Construction Projects, Risks Management, Techniques.

\section{INTRODUCTION}

Risk management is the systematic process of identifying, analyzing, and responding to project risk. It includes maximizing the probability and consequences of positive events and minimizing the probability and consequences of adverse events to meet the project objectives (PMI, 2000) [6]. The success or failure of any venture depends crucially on how we identify and deal with the risk factors which affect construction of our project.

Every construction activity no matter what its size and complexity are, involves risks, which may vary in their final affect on deliverables (Dey 2002; [3], Poon et al, 2004) [5]. And "no construction project is risk free. Risk can be managed, minimized, shared, transferred or accepted. It can not be ignored" (Lutham, 1994) [4]. Moreover, complexity is introduced in to construction projects due to the tendency of developing large-sized Mega projects, which involve intricate designs and novel materials, escalating the overall exposure to risk and uncertainty (Akintoye and MacLeod, 1997; [2], Abdelgawad and Fayek, 2010) [1]. Therefore, to respond to these threats and avoid the failure of projects due to unmanaged risks, risk management must be fundamental to project managers (Royer, 2000; [7] Raz et al, 2010) [8].

Construction projects have been inculcated with various numbers of risks hence the factors affecting the risks have to be identified, which calls for a proper attention for this study. The aim of this study is to identifying the key risk factors which affect construction projects and suggest affective recommendations for successful constructions of projects. detailed analysis of various construction risks factors which affect construction project such as the inadequate planning, poor adoption of site safety, supply and use of defective materials and poor resources management in construction project as well as effective recommendations for a successful attainment of project objective have been adopted. The paper is organized into six sections, section two dwells on objective, section three methodology section four analyses and results while section five estimates and present the results and section six concludes and makes a policy recommendations.

\section{OBJECTIVE}

The objective of this paper is to identify the key risk factors which affect construction process and present an affective recommendation for adoption to avert the threat which causes severity effect to construction project

\section{METHODOLOGY}

The paper adopted simple statistics method using qualitative data. A sample of 30 respondents was selected randomly from small and large construction companies in order to identify the key risks factors which affect construction process in India. 
The survey is done on 15 different construction companies. Totally 50 questions were asked which are meant to find out the key risk factors which affect construction process in their companies and to find out other various problems they face during construction. After the questionnaires have been collected, the analysis is done using Statistical Package for Social Sciences (SPSS). The responses of the questions have been coded as numerals which resulted in finding out the frequency and percentage using the cumulative percentage formula.

\section{ANALYSIS AND RESULT}

The figures below shows the analysis of results, the analysis was done using SPSS software in which the mean value as well as standard deviation of the mean for each risk factor was obtained. The analysis is categorized into two sections:
The general information of the various respondents and the responses of the selected respondents under the periods of the study.

\subsection{Years of Working Experience of the Respondents}

The figure 1 below shows the percentages of the working experience where by 6 to 10 constitute $33.3 \%$ while 11 to 15 account 30 percent of the respondent. 1 to $520 \%$ and 16 to $2010 \%$ and 20 above 20 years is $6.7 \%$ of the respondents.

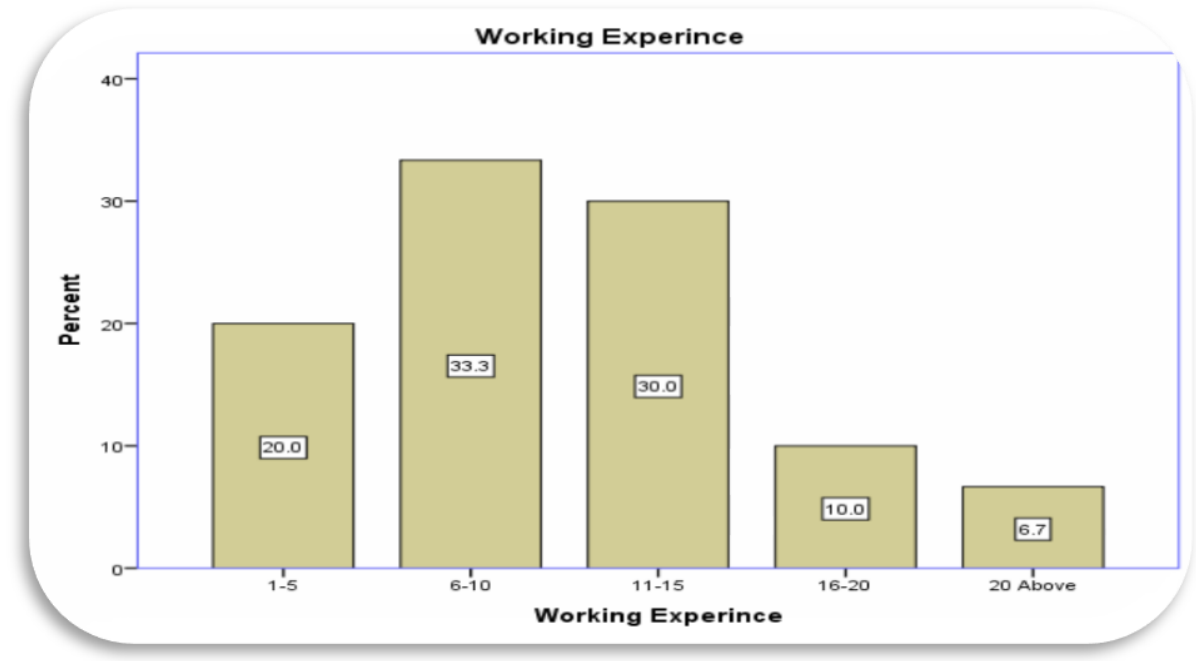

Fig-1: Years of working experience of the respondents

\subsection{Respondents Position}

The figure 2 indicated the positions of the respondents, mostly contractors and planning engineers, their percentages reveals highest percent of the respondent which account for about 33.3 percent of the respondent each, while site engineers 13.3 percent and others account for 12 percent of the respondents.

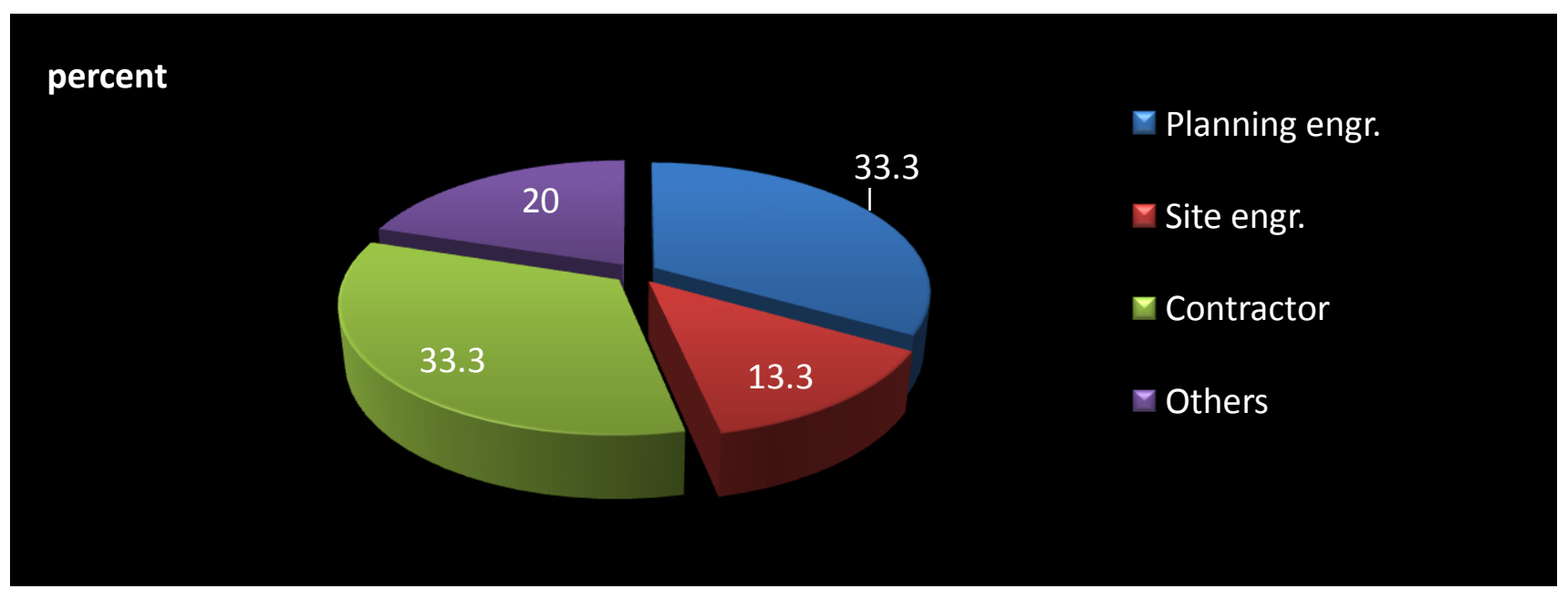

Fig-2: Respondents positions 


\subsection{Project Name}

Two important projects was given dues regards, these are road construction and site construction, these two types of project constitute $50 \%$ and $40 \%$ percent respectively. But in order to avoid bias and accurate results others construction companies has been analyzed this cover 10 percent of the respondent, the results of the project names is depicted in figure 3 below.

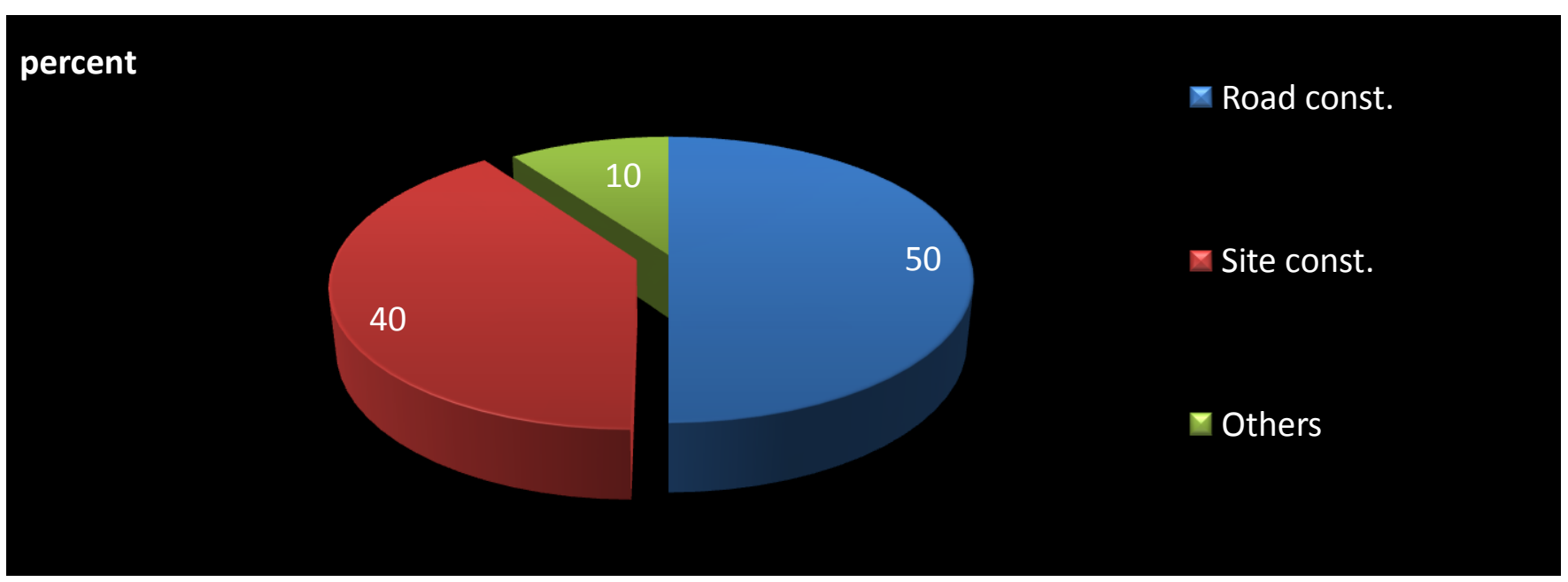

Fig-3: project name

\subsection{Inadequate Planning Causes Risk in}

\section{Construction Project}

It can be interpreted that $36.70 \%$ of the respondent strongly agreed that in-adequate planning causes risk in construction of project, while 6.70 percent of the respondent disagree and
30.00 percent of the respondents agreed and lastly $26.70 \%$ of the respondent are neutral. It can be concluded base on the respondent responses that inadequate planning causes risk in construction of project, since it score highest response from the survey conducted.

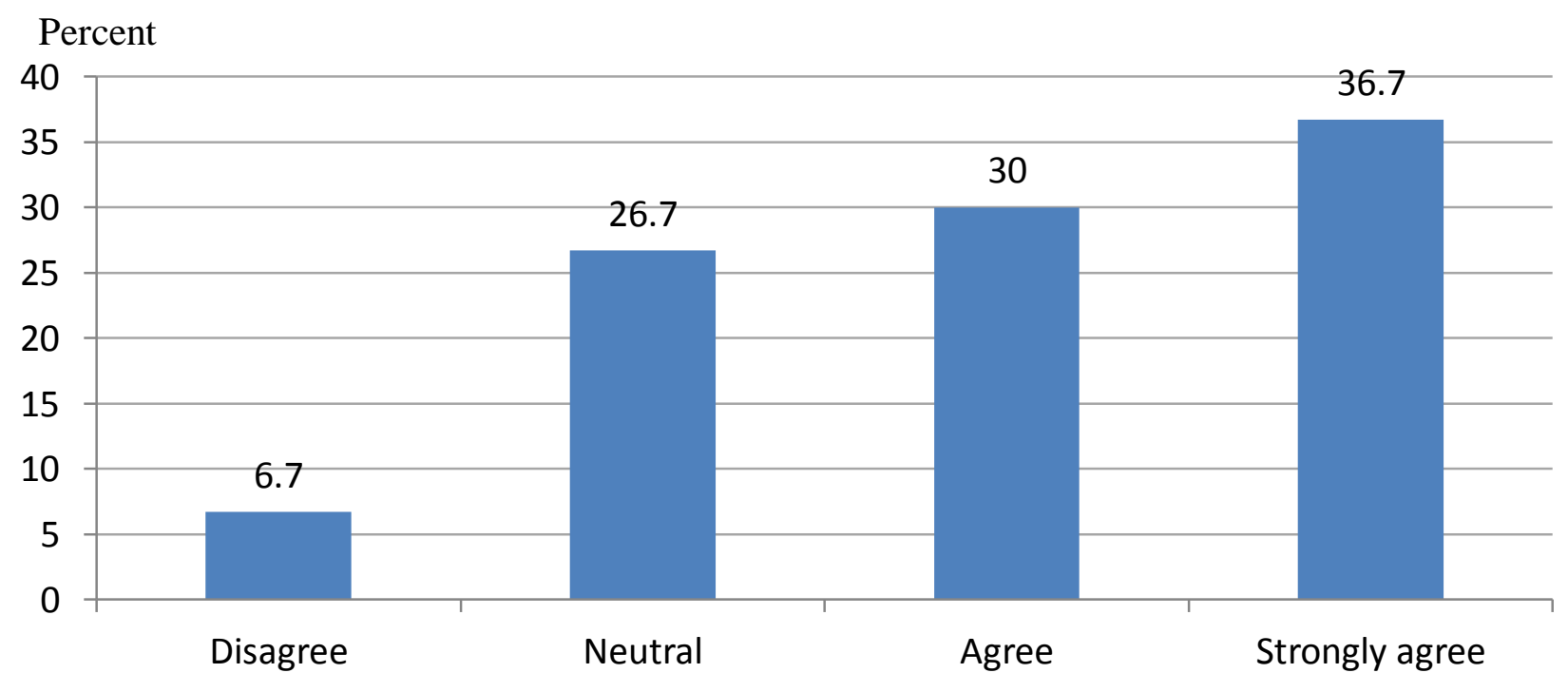

Fig-4: Inadequate planning causes risk in construction project

\subsection{Adoption of Site Safety Minimize Risks during Construction of Project}

In figure 5 below, $43.30 \%$ of the respondents strongly agreed that site safety minimizes risk while $40.00 \%$ of the respondents agreed so also $3.30 \%$ of the respondent disagree that site safety minimizes risk during construction of project. It can be concluded that majority of the respondents agreed that site safety minimizes risks during construction of project. 


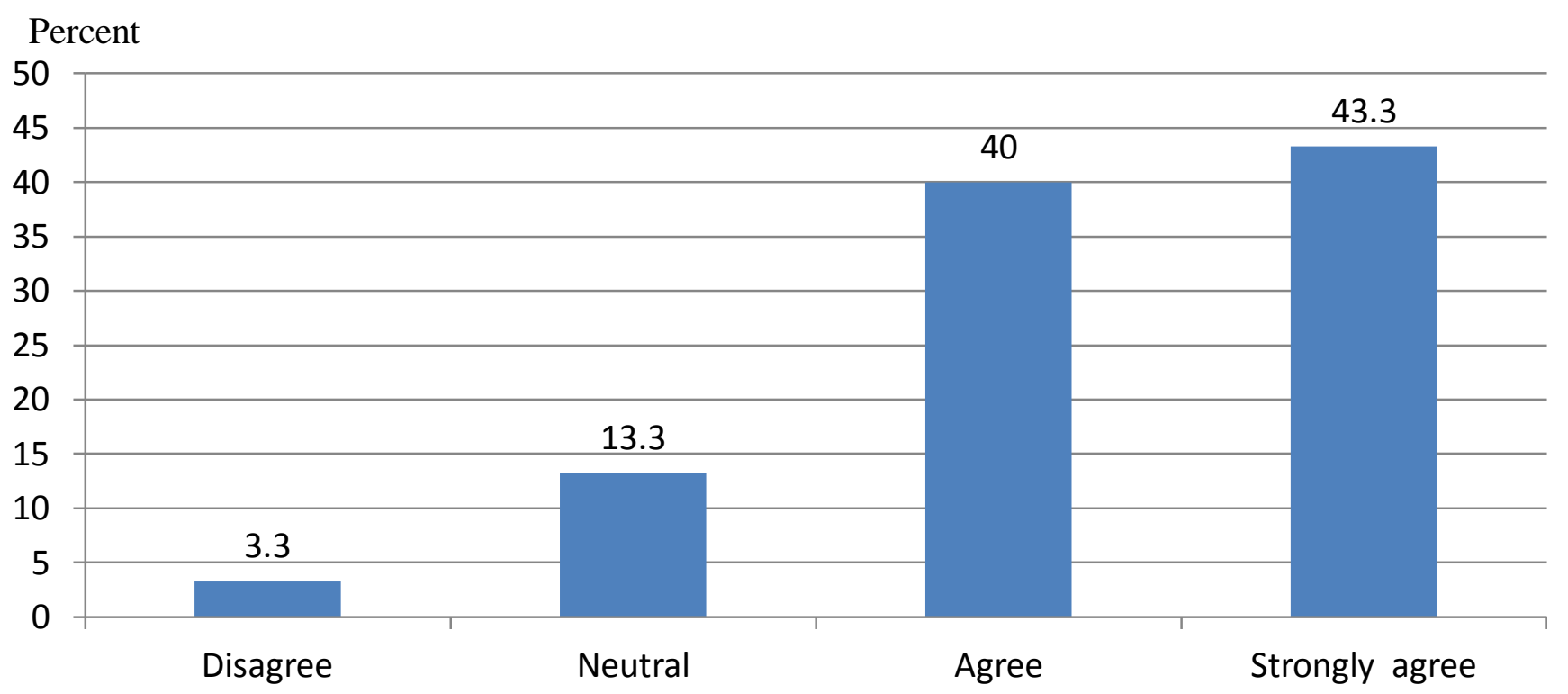

Fig-5: adoption of site safety minimizes risk in construction projects

\subsection{Supplies and Uses of Defective Material Causes}

\section{Risk in Construction Project}

From the figure below, $46.70 \%$ of the respondents agreed that use of defective material causes risks in construction of project while $10.00 \%$ of the respondent disagree, $26.70 \%$ of the respondents are neutral while 16.70 percent strongly agreed that the supply use of defective material causes risk in constructing project.

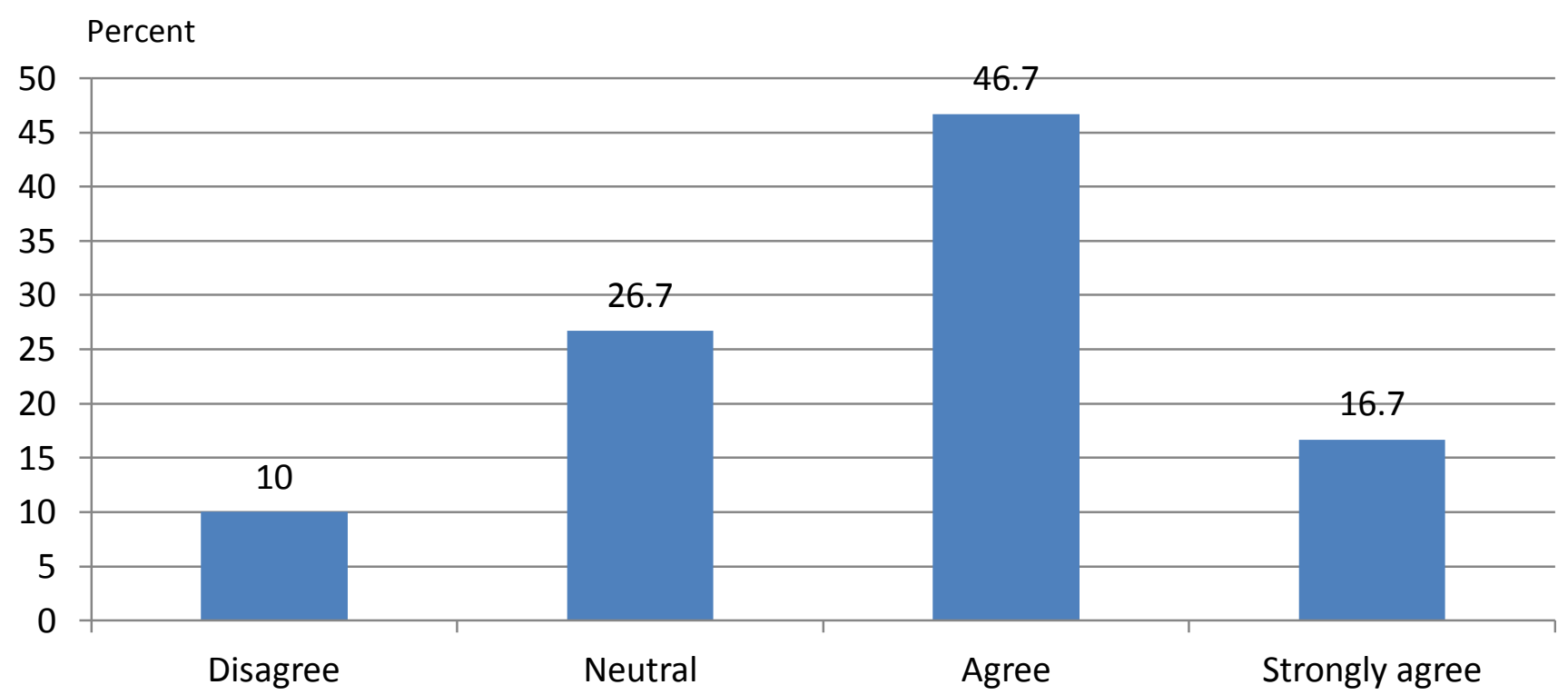

Fig-6: Supply and use of defective materials causes risk in construction projects

\subsection{Poor Resources Management Develops Risk in Construction of Project}

From the chart below, $56.7 \%$ agreed that poor resources management develops risk during construction of project and also $23.3 \%$ supported the above point while $20 \%$ percent of the respondents are neutral. Hence none of the respondent agreed with the poor resources management. Therefore, it can be concluded that poor resource management causes risk in construction process. 


\section{Percent}

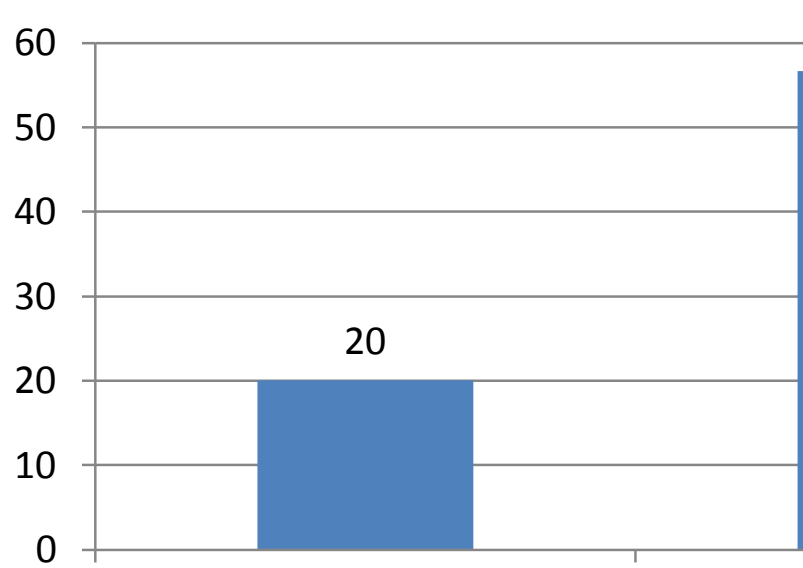

Neutral

56.7

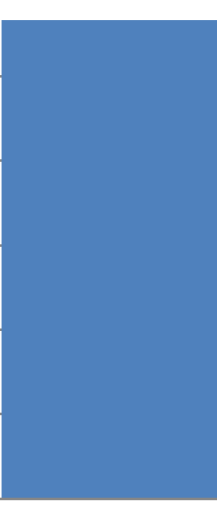

Agree

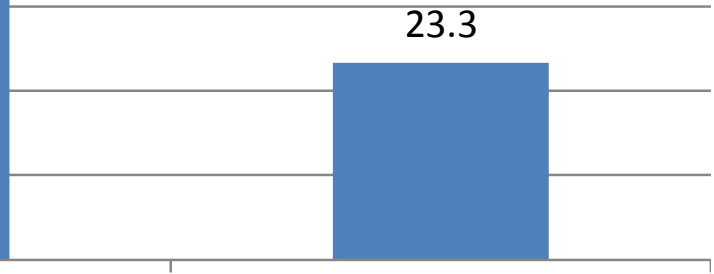

Strongly agree

Fig-7: Poor resources management develop risks in construction projects

Table-1: Other Findings/ Responses

\begin{tabular}{|c|c|c|}
\hline Questions & Variables & Percent $(\%)$ \\
\hline \multirow{5}{*}{$\begin{array}{l}\text { Do you agree that land acquisition is one of the factors of } \\
\text { construction risk? }\end{array}$} & Disagree & 16.7 \\
\hline & Strongly disagree & 6.7 \\
\hline & Neutral & 33.3 \\
\hline & Agree & 30.0 \\
\hline & Strongly agree & 13.3 \\
\hline \multirow{5}{*}{$\begin{array}{l}\text { Late delivery of construction materials to the site have a negative } \\
\text { effect to the construction project }\end{array}$} & Disagree & 10.0 \\
\hline & Strongly disagree & 3.3 \\
\hline & Neutral & 40.0 \\
\hline & Agree & 36.7 \\
\hline & Strongly agree & 10.0 \\
\hline \multirow{5}{*}{$\begin{array}{l}\text { Change in the scope of work is one of the factors which } \\
\text { constitute risk, do you agree? }\end{array}$} & Disagree & 30.0 \\
\hline & Strongly disagree & 6.7 \\
\hline & Neutral & 33.3 \\
\hline & Agree & 16.7 \\
\hline & Strongly agree & 13.3 \\
\hline \multirow{5}{*}{$\begin{array}{l}\text { Do you agree that shortage of equipment is one of the risk factors } \\
\text { that affect construction project? }\end{array}$} & Disagree & 20.0 \\
\hline & Strongly disagree & 6.7 \\
\hline & Neutral & 43.3 \\
\hline & Agree & 26.7 \\
\hline & Strongly agree & 3.3 \\
\hline \multirow{5}{*}{$\begin{array}{l}\text { Do you agree that poor quality of workmanship does not } \\
\text { negatively affect construction of a project? }\end{array}$} & Disagree & 23.3 \\
\hline & Strongly disagree & 26.7 \\
\hline & Neutral & 30.0 \\
\hline & Agree & 6.7 \\
\hline & Strongly agree & 13.3 \\
\hline \multirow{4}{*}{$\begin{array}{l}\text { Is shortage of material one of the factor which affects } \\
\text { construction of a project? }\end{array}$} & Disagree & 10.1 \\
\hline & Neutral & 53.3 \\
\hline & Agree & 33.3 \\
\hline & Strongly agree & 3.3 \\
\hline
\end{tabular}


From the table above, it can be interpreted that $30.3 \%$ of the respondents agreed that the land acquisition is one of the factors of construction risk, $33.3 \%$ are neutral, and $13.3 \%$ strongly support the point while $16.7 \%$ disagree but $6.7 \%$ of the respondents strongly disagree. Therefore, it is concluded that majority of the respondents agreed that land acquisition is one of the factors of construction risk.

$40 \%$ of the respondents are neutral on the point which stated that late delivery of construction materials to the site have a negative effect to the construction project but $46.7 \%$ of the respondents agreed on the point with support of $10 \%$ of the respondents, which strongly agreed. While, only $3.3 \%$ of the respondents disagree with the point, and $10 \%$ also strongly disagree. It is concluded that late delivery of construction materials to the site have a negative effect to the construction project.

Similarly, $33.3 \%$ of the respondents are neutral on the point which says change in the scope of work is one of the factors which constitute risk in construction project while $30 \%$ disagree, $16.7 \%$ agreed, $13.3 \%$ strongly agreed with the point, and $6.7 \%$ of the respondents strongly disagree with the point. Therefore, it is clear that majority of the respondents agreed that change in the scope of work is not a factor which constitute risk in construction project.

It is clear in the above table that $43.3 \%$ of the entire respondents are neutral on the point which stated that shortage of equipment is one of the risk factors that affect construction project, $26.7 \%$ agreed, $20 \%$ disagree, $6.7 \%$ strongly disagree and $3.3 \%$ strongly supported the point. It is clear that going by the high percentage of the decided respondents agreed that shortage of equipment is one of the factors that affect construction project.

$30 \%$ of the respondents are neutral on the point which stated that poor quality of workmanship does not negatively affect construction of a project but $26.7 \%$ of the respondentS strongly disagree, and $23.3 \%$ also disagree with the point, it is only $13.3 \%$ with support from $6.7 \%$ of the respondents that agreed with the point. Therefore, it can be concluded that majority of the respondents agreed that poor quality of workmanship negatively affect construction of project.

In addition, $53.3 \%$ of the respondents are neutral about the point which says shortage of materials is one of the factors which affect construction project, $33.3 \%$ agreed, and $10.1 \%$ disagree while $3.3 \%$ of the entire respondents strongly agreed with the point. Therefore, the majority of the decided respondents agreed upon the shortage of materials is one of the factors which affect construction of a project.

\section{MAJOR FINDINGS AND DICUSSION}

From the empirical results it was identified that inadequate planning is among the factors which causes risk in construction projects: If adequate planning of the entire project is not observed due to negligence or inexperience it may lead to loss or even failure of the project.
Poor adoption of site safety is among the factor which causes risk in construction projects: Safety rules and regulations are the most essential process which should not be neglected in every construction project activities. Negligence or ignorance on site safety leads to the damage of properties, hazard to environment, injury to workers and even loss of life.

Supply and use of defective materials is among the factors which causes risk in construction project: It is a threat to the contractor, owner and the environment where the project is situated if defective materials are supply and use in project, the project may be completed but its life span may be shorter.

Poor resources management develops risk in construction project: All the Men (workmen), Materials, Machineries, Money and Time available for construction if not efficiently and effectively manages, it may lead to great loss or immediate failure of the entire project.

\section{CONCLUSION AND RECOMMENDATION}

Risk management in construction of any project is very essential and a process to be giving priority by every construction company, larger, medium or smaller sized. The success of every construction project mostly is determined by the ability of the construction team to manage the risk and the process of implementing the project. it is conclusively identified that adequate planning, adoption of site safety, use of good and quality materials in construction as well as effective and efficient use of all the available resources are among the forefront factors for success that mitigate the amount of risk in construction project under the period of the study.

Therefore, to eliminate if not completely eradicate the number of risks usually encounter during construction of project one have to fully identify the factors that causes risk in construction of project and a possible process of mitigating them. For a project to be successful the following recommendations are hereby presented:

$>$ Adequate planning should be provided before the commencement of project construction.

$>$ Safety, rules and regulations in construction site should fully be maintained from the initial to final stage of construction.

$>\quad$ Durable and quality materials for construction should be supply and use properly.

$>$ Efficient and Economical use of all the available resources should be adopted by all members of construction team.

$>$ Land, Materials, Machineries and all other needed equipment should be supply immediately for effective utilization.

$>$ Effective communications and corporations between all members of construction team should be adopted.

$>$ Well trained and experienced workmen should be employed where necessary. 


\section{REFERENCES}

[1]. Abdelgawad, M. and Fayek, A. R., 2010. Risk management in the construction industry using combined fuzzy FMEA and fuzzy AHP. Journal of Construction Engineering and Management, ASCE, Vol. 136, No. 9, pp. 10281036.

[2]. Akintoye, A.S. and MacLeod, M.J., 1997. Risk analysis and management in construction. International Journal of Project Management, Vol. 15, No.1, pp. 3138.

[3]. Dey, P.K., 2002. Project Risk Management: A Combined Analytic Hierarchy Process and Decision Tree Approach. Cost Engineering, Vol. 44, No. 3, pp. 1326.

[4]. Latham, M. (1994), "Constructing the team" HSMO.

[5]. Poon, S.W., Chen, H., and Hao, G.L., 2004. Cost Risk Management in West Rail Project of Hong Kong. AACE International Transactions, pp. 15.

[6]. Project Management Institute. (2004). A Guide to the Project Management Body of Knowledge. Newtown Square, Pennsylvania: PMI. ㄴ. (2000). A Guide to the Project Management Body of Knowledge. Newtown Square, Pennsylvania: PMI.

[7]. Royer, P.S., 2000. Risk management: The undiscovered dimension of project management. Project Management Journal, Vol. 31, No.1, pp. 613.

[8]. Raz, T., Shenhar, A.J. and Dvir, D., 2002. Risk management, project success, and technological uncertainty. R\&D Management, Vol. 32, No. 2, pp. 101109.

\section{BIOGRAPHIES}

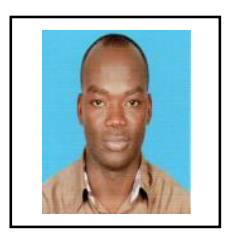

Shuaibu Saminu

(PG Student)

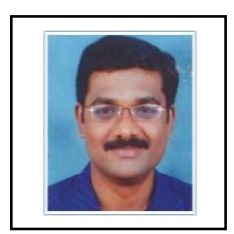

Mr. J. Rajprasad

Assistant Professor (OG)

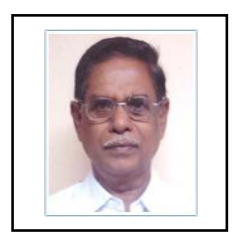

Dr. Thamilarasu ph D.

Professor 